\title{
The Comparison of Students' Reading Comprehension Between Natural Science and Social Science Students at State Senior High School 1 Tapung
}

\author{
Darliza Listari \\ Universitas Islam Negeri Sultan Syarif Kasim Riau, Indonesia \\ darlizalistari96@gmail.com \\ Roswati \\ Universitas Islam Negeri Sultan Syarif Kasim Riau, Indonesia \\ roswati@uin-suska.ac.id
}

\begin{abstract}
The purpose of this study is to know the comparison of students' reading comprehension in descriptive text between natural science and social science students at State senior High School 1 Tapung. The total population of this research was 210 students which consisted of seven classes, the researchers took $20 \%$ of the population as the sample by stratified random sampling. The design of this research was quanitative used comparative research. In collecting the data, the researchers distributed a reding comprehension test based on the indicators. After analyzing the data, the researchers found that that there was a significant difference of reading comprehension between natural science and social science students on reading descriptive text comprehension at the tenth grade of State Senior High School 1 Tapung. It was considered by $\mathrm{t}$ obtained $=3.329$ that was higher than t-table either at $5 \%=2.021$ or $1 \%=2.704$. It means that Ha was accepted and Ho was rejected. From the research finding, it showed that there was a significant difference in reading comprehension of descriptive text between natural science and social science students at the tenth grade of State Senior High School 1 Tapung.
\end{abstract}

Keywords: Comparison, Natural Science and Social Science Students, Reading Comprehension in Descriptive Text. 


\section{Introduction}

Reading is one of the language skills that should mastered of English language learners. Reading is the ability to recognize the messages from written language. It requires readers' ability to translate the meaning from formal language into informal language. According to Dorn and Soffos in Nurdiana and Amelia (2017), reading is a complex process involving a network of cognitive actions that work together to construct meaning. Reading involves recognizing and comprehending words and sentences patterns. According to Wooley (2011), reading comprehension is process of making meaning from text. The goal, therefore, is to gain an overall understanding of what is described in the text rather than to obtain meaning from isolated words or sentences.

In this research, researchers focused in reading comprehension about descriptive text. Descriptive text is one of the text types that are learned in Senior High School, especially in tenth grade. According to Stanley (1988), description presents the appearance of things that occupy space, whether they are objects, people, buildings or cities. In line with Syafii et. al (2011), descriptive text is the text that used to describe a place, a thing, or a person.

State Senior High School 1 Tapung is one of the formal schools in Kampar regency. As a formal school, this high school is also offering the English subject to students especially in term of reading comprehension skill. Based on curriculum 13 (K13) that is used at tenth grade students in State
Senior High School 1 Tapung, the purposes of learning descriptive text are: The basic competency of this subject is to understand the social function, structure of text, and language features of descriptive text about person, buildings, place, etc. The second one is processing, analyzing, and offering in abstract and concrete concerned development they have learned at school with self-employed, and able to use method appropriate the rules. (National Education Department).

Based on the preliminary observation of the researchers on April, 2017, the researchers interviewed a teacher of English, Mrs. Sri that taught English for the tenth grade of State Senior High School 1 Tapung. The result of interview is some of students have problems and difficulties of reading English especially reading descriptive text. Their ability in reading comprehension is still far from the expectation of the curriculum. It is provided by the result of minimum passing grade that achieved by the students. Based on the researchers's finding, the minimum passing grade for reading comprehension of descriptive text in State Senior High School 1 Tapung is 75 whereas some of students could only less than 75 .

The problem above is caused by several factors, whether it is from the students itself or from the outside. One of the factors is students' cognitive process. Cognitive process is something happening in the students' mind. According to Adams and Collins in Sheridan (1981) The student has present in cognitive structure schemata which 
constitute a cognitive filter through which one views the world and from which one predicts or makes inferences about what is read. Schemata is represent generic concepts which are stored in memory. A more recent theory of reading comprehension is called "schema theory". The goal of schema theory is to describe interaction between what is in the text and how that information is shaped and stored by the reader.

At the State Senior High School 1 Tapung, it has two majors, Natural Science major (IPA) and Social Science major (IPS). Natural science and social science are two subjects that differ from each other in terms of their subject matter. Natural sciences are the branches of science that go into the details of the natural world by using scientific methods. According to Stenberg in Sapitri (2017), the students who study in natural science tend to think logically and based on the fact. He also categorized students who study in natural science major into conservative.

According to Gardner (2006) ability to think logical, detecting pattern, scientific reasoning and deduction; analyse problems, perform mathematical calculations, understand relationship between cause and effect towards a tangible outcome or result is logical mathematical intelligence. Thus, Natural science students is logical mathematical intelligence.

On the other hand, social science is any study that is centered on society and its development. According to Stenberg in Sapitri (2017), the students who study in social science major tend to memorize and recall information. He also categorized students who study in social science major into liberal.

On the other hand, in line with Gardner (2006), ability to relate to others; perception of other people's feelings; interpretation of behaviour and communications; understands the relationship between people and their situations including other people or human contact is interpersonal intelligence. Thus, social science students is interpersonal intelligence.

The students of the two majors have different cognitive process in doing something. The teacher belief that the students of natural science are better than students of social science. It caused of the different way of their cognitive intelligence of processing something, and also by looking at the behavior of natural science and social science students. The ways they express their ideas is not similar and depend on their characteristics. Unfortunately, the researchers can't judge someone's intelligency by his/her behavior instead the resarcher need to test them.

Therefore, the researchers interested in investigating the reading comprehension of descriptive text between natural science students who belong to logic mathematic intelligence and social science students who belong to inter-personal intelligence.

Based on the explanation above, the researchers interested in researching the problems above in to a research project entitled "The Comparison of Students' Reading Comprehension in Descriptive Text between Natural 
Science and Social Science Students at State Senior High School 1 Tapung”

\section{Research Method}

This research was a quantitative research. It used comparative research. According to Gay (1990), comparative study is explanation of similarities and differences, but comparative tends to emphasize the differences or contrast rather than the similarities. It means that the researchers should focus on finding the differences to sets of the data. In short, comparative study focus on differences between groups.

This research only involves two independent variables which are natural science symbolized "X1", social science symbolized ' $\mathrm{X} 2$ ", and student's reading comprehension symbolized "Y" as dependent variable. The comparative research is appropriate to find out the comparison of students' reading comprehension in descriptive text between natural science and social science students at State Senior High School 1 Tapung.

This research was conducted at state senior high school 1 Tapung. It is located on Petapahan-Minas street KM.93 Indrasakti, Tapung, Kampar. The total population consists of seven classess, which 3 classess for natural science major, 4 classess for social science major. The number of population was 210 students. According to Arikunto (2006), if the subject is less than 100 people should be taken altogether, if the subject is large or more than 100 people can be taken $10-15 \%$ or $20-25 \%$ or more.
In this research, the researchers used proportional stratified random sampling. Gay (2012) explains that proportional stratified sampling is how to select a sample in which the researchers identify subgroups. They are natural science and social science students group. In State Senior High School 1 Tapung, the total population was 210 students. The sample taken $20 \%$ of the population. Thus, the sample totalwas $20 \%$ x 210 students $=42$ students.

The subject of this research was the tenth grade of State Senior High School 1 Tapung. Meanwhile the object of this research was a comparison between natural science and social science students on reading comprehension of descriptive text.

The indicators of variable $\mathrm{Y}$ or reading comprehension as dependent variable proposed by King and Stanley in Amelia and Nurdiana (2017) are:

1. Both natural science and social science students are able to findthe main idea of descriptive text.

2. Both natural science and social science students are able to find the factual information of descriptive text.

3. Both natural science and social science students are able to find the meaning of vocabulary of descriptive text.

4. Both natural science and social science students are able to identify the reference of descriptive text.

5. Both natural science and social science students are able to 
identify the inference of descriptive text.

\section{Technique of Collecting Data}

In this research, the researchers used test techique to collect the data of students' reading comprehension. As what focus in this research, the test was about reading comprehension on descriptive text. 25 questions of comprehension descriptive text were created based on five indicators as what have been explained in the operational concept. In multiple choices, the researchers provided four possibility answers included A, B, C, and D for each item and samples chose one correct answer only

\section{Technique of Data Analysis}

In analyzing the comparison of reading comprehension between natural science and social science students on descriptive text at the tenth grade of State Senior High School 1 Tapung, the researchers analyzed the data using the statistical analysis. In this research, the researchers used t-test by using SPSS as the main technique to analyze the data to know comparison between natural science and social science students in reading comprehension of descriptive text. In reference to Pallant (2011), an independent samples t-test is used when we want to compare the mean score, on some continuous variable, for two different groups of participants.

Because the score cumulative minimum standard of the tenth grade is 75 , the students who got score $\geq 75$ passed the test. However, the students who got score $\leq 75$ didnot pass the test. in addition, to find out the level of students' reading comprehension, the researchers used following measurement:

The Classification of Students' Score

\begin{tabular}{|l|l|l|}
\hline No & Score & Category \\
\hline 1. & $81-100$ & Very good \\
\hline 2. & $61-80$ & Good \\
\hline 3. & $41-60$ & Mediocre \\
\hline 4. & $21-40$ & Bad \\
\hline 5. & $1-20$ & Poor \\
\hline
\end{tabular}

Arikunto, 2010.

\section{Research Finding}

To analyze the students' reading comprehension, the researchers used score classification.

1. Natural science students' reading comprehension of descriptive text

The researchers found that the mean score of natural science students' reading comprehension of descriptive text was 78. Thus, it can be concluded that the natural science students' reading comprehension in descriptive text was categorized into "Good" level.

\section{The Classification of Natural Science} Class Score

\begin{tabular}{|l|l|l|l|l|}
\hline No & $\begin{array}{l}\text { Categ } \\
\text { ory }\end{array}$ & $\begin{array}{l}\text { Scor } \\
\text { e }\end{array}$ & $\begin{array}{l}\text { Fre } \\
\text { que } \\
\text { ncy }\end{array}$ & $\begin{array}{l}\text { Perce } \\
\text { ntage }\end{array}$ \\
\hline 1. & Very & $81-$ & 5 & $26.3 \%$ \\
\hline
\end{tabular}




\begin{tabular}{|l|l|l|l|l|}
\hline & good & 100 & & \\
\hline 2. & Good & $\begin{array}{l}61- \\
80\end{array}$ & 14 & $73.7 \%$ \\
\hline 3. & $\begin{array}{l}\text { Medio } \\
\text { cre }\end{array}$ & $\begin{array}{l}41- \\
60\end{array}$ & - & - \\
\hline 4. & Bad & $\begin{array}{l}21- \\
40\end{array}$ & - & - \\
\hline 5. & Poor & $1-20$ & - & - \\
\hline
\end{tabular}

The table above provides information concerning; there were 5 categories for the students' reading comprehension of descriptive text of natural science class. The frequency of very good category was $5(26.3 \%)$, the frequency of good category was 14 (73.7\%), and there was no student categorized into mediocre, bad and poor category. The table shows that highest percentage of natural science class was $73.7 \%$. Thus, the majority of the students in natural science class were classified into good.

2. Social science students' reading comprehension of descriptive tetx

The researchers found that the mean score of social science students' reading comprehension of descriptive text was 70. Thus, it can be concluded that the social science students' reading comprehension in descriptive text was categorized into "Good" level.

The Classification of Social Science Class Score

\begin{tabular}{|l|l|l|l|l|}
\hline $\begin{array}{l}\text { N } \\
\text { o }\end{array}$ & $\begin{array}{l}\text { Categ } \\
\text { ory }\end{array}$ & $\begin{array}{l}\text { Scor } \\
\text { e }\end{array}$ & $\begin{array}{l}\text { Frequ } \\
\text { ency }\end{array}$ & $\begin{array}{l}\text { Perce } \\
\text { ntage }\end{array}$ \\
\hline 1. & $\begin{array}{l}\text { Very } \\
\text { good }\end{array}$ & $\begin{array}{l}81- \\
100\end{array}$ & 2 & $8.7 \%$ \\
\hline
\end{tabular}

\begin{tabular}{|l|l|l|l|l|}
\hline 2. & Good & $\begin{array}{l}61- \\
80\end{array}$ & 16 & $69.6 \%$ \\
\hline 3. & $\begin{array}{l}\text { Medi } \\
\text { ocre }\end{array}$ & $\begin{array}{l}41- \\
60\end{array}$ & 5 & $21.7 \%$ \\
\hline 4. & Bad & $\begin{array}{l}21- \\
40\end{array}$ & - & - \\
\hline 5. & Poor & $1-20$ & - & - \\
\hline \multicolumn{5}{|c|}{ The table above provides }
\end{tabular}
information concerning; there were 5 categories for the students' reading comprehension of descriptive text of social science class. The frequency of very good category was $2(8.7 \%)$, the frequency of good category was 16 $(69.6 \%)$, the frequency of mediocre category was $5(21.7 \%)$, and there was no student categorized into bad and poor category. The table shows that highest percentage of social science class was $69.6 \%$. Thus, the majority of the students in social science class were classified into good.

The data analysis indeed the explanation about natural science and social science students' reading comprehension in descriptive text of the tenth grade at State Senior High School 1 Tapung, the researchers discuss some finding of this research as follows:

1. Comparison between value $t_{\text {table }}$ with $\mathrm{t}_{\mathrm{o}}$ :

If $t_{o}>t_{t a b l e}, H a$ is accepted and Ho is rejected.

If $t_{o}<t_{\text {table, }}$ Ho is accepted and $\mathrm{Ha}$ is rejected.

$\mathrm{df}=\mathrm{N}-\mathrm{nr}$

$\mathrm{df}=42-2=40$ at $5 \%$ of significance is

2.021 and at $1 \%$ of significance is 2.704 . 
Ho is rejected when $t_{0} \quad(t-$ obtained) $>\mathrm{t}$ table. Thus, because 2.021 $<3.329>2.704$, the null hypothesis is rejected and the alternative hypothesis is accepted. Value proved that there is a significance difference between natural science and social science students' reading comprehension in descriptive text of the tenth grade at State Senior High School 1 Tapung.

\section{The sig. Value}

Based on the table IV.11 above, it can be seen that the sig. value are $0.002<0.05$. It means that the sig. value is less than the 0.05 (alpha), it proves that $\mathrm{Ha}$ is accepted and $\mathrm{Ho}$ is rejected.

3. The mean of natural science and social science students' reading comprehension

The mean of natural science students' reading comprehension in descriptive text score accessed from 19 students was 78, thus, the majority of the natural science students were classified into Good. In other hand, the mean of social science students' reading comprehension in descriptive text score accessed from 23 students was 70, thus, the majority of the social science students were classified into Good.

These all findings can be drawn the differences between natural science and social science students' reading comprehension. Therefore, it can conclude that natural science and social science students of the tenth grade at State Senior High School 1 Tapung are different in reading comprehension of descriptive text.

\section{Conclusion and Suggestion}

Referring to the research findings un the previous chapter, finally the researchers makes some conclusion as follows:

1. Natural science students' reading comprehension of descriptive text at the tenth grade of State Senior High School 1 Tapung is categorized into good level. They resulted 78 as their mean score and the percentage of students who obtained the passing score is $73.7 \%$.

2. Social science students' reading comprehensionof descriptive text at the tenth grade of State Senior High School 1 Tapung is categorized into good level. They resulted 70 as their mean score and the percentage of students who obtained the passing score is $69.6 \%$.

3. Statistically, by orienting the number of significance, the sig. 2tailed $(0.002<0.05)$, values obtained prove that there is a significant. By comparing between $\mathrm{t}$ obtained with $\mathrm{t}$ table. $\mathrm{T}$ obtained to $t$ table from $\mathrm{df}=\mathrm{n}-2=42-2=40$, it is found that level of significant $5 \%$ is 2.021 , and the level of significant $1 \%$ is 2.704. thus, because $\mathrm{t}$ obtained $>\mathrm{t}$ table $(3.329$ $>2.021)$, it means that null hypothesis (Ho) is rejected while the alternative hypothesis (Ha) is accepted. There was a significant difference in reading comprehension of descriptive text between natural science and social science students at the tenth grade of State Senior High School 1 
Tapung. Based on the data analysis, it shows that natural science students are more better in learning than social science class for students' reading comprehension of descriptive text at the tenth grade of State Senior High School 1 Tapung.

Considering the comparison between natural science and social science students on reading comprehension of descriptive text at the tenth grade of State Senior High School 1 Tapung, the researchers would like to give some suggestion: The first suggestion for teacher. It is important for english teacher to give more explanations and more exercises to the students in comprehending descriptive text, especially to find the main idea, find factual information, guess the vocabulary, identify the reference, and identify the inference to increase the students' interest in readng descriptive text.

The second suggestion for students. The students should pay more attention to the lesson explained by the teacher, and must ask the teacher what they do not understand in learning process. The students may not think thet english subject is difficult to learn, and also should do the discussion and share information in order to improve their comprehension in reading the english text. The last, The students should more often read the english books in order to increase their knowledge.

The third suggestion for school. The school should pay attention to the english subject by facilitate the media in learning, and make english program to increase students' interesting in english.

\section{Reference}

Arikunto, S.(2010). Prosedure Penelitian Suatu Pendekatan Praktik. Jakarta: Rineka Cipta.

Broughton, G., Christopher, B., Roger, F., Peter, H, \& Anita, P.(1980).Teaching English as a Foreign Language. New York: Routledge.

Brown, D. H.(2003). Language Assessment Principles and Classroom Practices. San Francisco: San Francisco State University. P. 189.

Burt, M., Peyton, J.K., \& Adams, R. (2003). Reading and Adult English Language Learners: A Review of the Research. Washington, DC: Center for Applied Linguistics.

Carver, L., and Pantoja, L.(2015).Reading Basic for All Teachers: Supporting The Common Core. Boulevard, SD:

Rowman\& Littlefield Publishing Group, Inc.

Dorn, Linda J., and Carla Soffos.(2005). Teaching for Deep Comprehension: a reading workshop approach. United State: Stenhouse. P.6.

Gardner, H.(2006). Multiple Intelligences. New York: Ingram Publisher.

Gay L.R., Geoffrey E. Mills., \& Peter W. Airasian. (2012). Educational Research: Competencies for Analysis and Applications Tenth Edition. United states America: 
Pearson Education.

Harrison, C.(2004). Understanding Reading Development. London: Sage Publication.

Klingner, J.K., Vaughn, S., \& Boardman, A.(2007). Teaching Reading Comprehension to Students with Learning Difficulties. New York, NY: The Guilford Press.

Ledoux, Stephen F.(2002). Defining Natural Science Journal. Vol 5, No 1.

Moreillon, J.(2007). Collaborative Strategies for Teaching Reading Comprehension. Chicago: America Library Association. P.10.

Muniroh, S.(2016). The Comparative Study of the Eleventh Natural Science and Social Science Students' Listening Skill Affected on Motivation. UNISSULA.

Nurdiana, and Rizki Amelia.(2017). Interpretive Reading. Pekanbaru: Kreasi Edukasi.

Nuril, F.A.(2015). A Comparative Analysis between Natural Science and Social Science Students' Critical Thinking in Writing Analytical Exposition Text. UPI: repository.upi.edu.

Pallant, J.(2011). SPSS Survival Manual the Fourth Edition. Australia.

Richards, Jack C and Richard Schmidt.(2010). Longman Dictionary of Language Teaching and Applied Linguistics 4th Edition. London:Pearson
Education Limited.

Sapitri, R. (2017). Cognitive Process of the Students in Writing Argumentative Text Journal. Vol 2 , no 1 .

Setiadi, L., Risuli H., Teguh S., Josephine S. Kustanti.(2012). Seri Pendalaman Materi Bahasa Inggris untuk SMA/MA. Jakarta: ESIS.

Snow, C.(2002). Reading for Understanding: Toward A Research and Development Program in Reading Comprehension. U.S Department Of Education: Library of Congress Caloging in Publication Data. P.11.

Stanley, L. (1988). Ways to Writing. New york: Macmillan.

Syafii S, M., M Fauzan Ansyari, \& Jonri Kasdi. (2011). The Effective Paragraph Development The Process of Writing for Classroom Settings. Pekanbaru: Lembaga Bimbingan Belajar Syaf Intensive (LBSI). P.5.

Syafii S, M.(2015). From Paragraphs to a Research Report: a Writing of English for Academic Purposes. Pekanbaru: SUSKA PRESS.

Tarnkersley, K.(2005). Literacy Strategies for Grades 4-12: Reinforcing the Threads of Reading. Virginia: Association for Supervision and Curriculum Development (ASCD). P.108-110. 
Darliza Listari, Roswati - The Comparison of Students' Reading Comprehension ...

Woolley, G. (2011). Reading

Comprehension: Assisting

Children WithLearning

Difficulties, New York, NY:

Springer Science + Business

Media B.V. 